\title{
Urban Growth versus Environmental Sustainability - A Study on the Peripheral Expansion of Bengaluru and the Emergence of Nandagudi Township
}

\author{
Kentsel Büyümeye Karşı Çevresel Sürdürülebilirlik - Bengaluru'nun Büyümesi ve \\ Nandagudi İlçesinin Ortaya Çıkışı Üzerine Bir Çalışma
}

Priyadarshini SEN

\section{ABSTRACT}

Suburbs may be defined as regions located on the periphery, or outside the center of any urban settlement. Their growth is best described as a mysterious phenomenon, which in recent years has been viewed as the most suitable alternative for the construction of a residential environment to cater for ever-expanding populations in major cities, away from crowds and density, and pollution of various types. In a developing country like India, where urbanization has overtaken maintenance of a rural livelihood, metropolitan cities face the question of accommodation in all its aspects. Bengaluru, the one-time paradise of pensioners, is now the IT capital of India. It is engaged in efforts to relocate its growing population through the creation of better roads, communication and housing, and of course through decentralizing the same to its peripheries. Nandagudi is one of five locations near the city where urban planners wish to relocate the excess population of the city with the help of planned housing, roads, industries and easy commuting facilities. It is northeast of Bengaluru, and also happens to be an agriculturally rich area, known especially for its milk producing and bee keeping activities. Hence, the area poses the eternal question of sustainability versus development. This article aimed to examine the issues involved here from the perspective of both the locations involved: on the one hand is the city of Bengaluru, faced with the urgent need to relocate its growing population, while, on the other is the group of villages that make up the demarcated area of Nandagudi, and the inhabitants of these villages, who remain entirely unaware of the urban expansion activities that will take place at the cost of their traditional livelihoods.

\section{ÖZET}

Uydu kentler, herhangi bir ana kentin yerleşim merkezinin dışındaki bir muhitte yer alan bölgeler olarak tanımlanabilir. Uydu kentlerin büyümesi gizemli bir fenomen olmakla birlikte büyük şehirlerin giderek artan nüfuslarının ihtiyacını karşılamak için inşa edilen yerleşim alanlarının farklı tür ve yoğunluklardaki kirlilikten ve kalabalıktan uzak en uygun seçeneği olarak görülmektedirler. Kentleşmenin kırsal yaşamı sürdürme üzerine üstünlük kurduğu Hindistan gibi gelişmekte olan bir ülkede büyük şehirler her bakımdan barınma sorunuyla yüzleşmektedirler. Bir zamanlar emeklilerin cenneti, şimdiyse Hindistan'ın Bilişim Başkenti olan Bengaluru, daha iyi yollar, iletişim, konut ve tabi ki sorumluluğu yerel merkezler arasında dağıtma yoluyla artan nüfusunu başka bölgelere taşımaya çalışmaktadır. Bengaluru şehir planlayıcılarının konut, yollar, sanayi ve şehir merkezine kolay ulaşım olanakları vasıtasıyla bu fazla nüfusu taşımayı planladıkları beş şehirden biri Nandagudi'dir. Bengaluru'nun kuzeydoğusunda özellikle süt üretimi ve arıcılık başta olmak üzere tarımsal açıdan da zengin olan Nandagudi adındaki bu uydu kent başı ve sonu olmayan sürdürülebilirliğe karşı büyüme sorunu hakkında sorular ortaya atmaktadır. Bu çalışmanın amacı, bir taraftan Bengaluru'nun artan nüfusunu bir an önce başka bir yere taşıma zorunluluğunu taşıdığı diğer taraftan ise Nandagudi köy halkının geleneksel geçim kaynakları pahasına bu tür kent genişletme faaliyetleri hakkında bilgisiz kaldığı öylesi bir dürbünden bu durumu incelemektir. 


\section{Introduction}

For cities and towns, planning issues are of two general kinds. First there is a need to think ahead to accommodate the city's growth-deciding which lands should be built on and when, and whether they should 'Suburb is an attempt to 'marry' a town and country, and to create for middle classes, middle cultures in middle spaces as in middle America, Britain or Australia." Silverstone, R. be used for residential development, for industry or for some more specialized function, such as a shopping centre or playing fields. Eventually, more detailed plans would also be required to determine the layout of every piece of land. The street networks need to be designed; sites have to be reserved for schools and parks, shops, public buildings and religious institutions; provisions had to be made for transit services and utilities; and development standards would be set and design ideas, to be tested in order to ensure the desired environmental quality.

A second group of issues concerns those parts of the community that are already settled on the otherwise demarcated new urban areas. Planners distinguish between areas where change is not desired and those where change is either unavoidable or judged to be needed. In the former case, the concern is for maintaining the built environment at its existing quality, regardless of pressures for change. This applies particularly to inner-city neighbourhoods which face pressures for apartment redevelopment or for streets to be widened to permit through traffic. In the latter case, the problem is to facilitate the changes that are considered most desirable. In one situation this may mean that a deteriorating area has to be upgraded; in another it may mean that buildings have to be demolished to allow their sites to be used in a new and different way. The problems of rapidly changing downtowns, of outdated industrial and warehousing districts, and of inner-city neighbourhoods experiencing a complex mix of social and physical changes all have to be dealt with by planners and public authorities. Urban environments continue to change and as cities age, it becomes more difficult and more expensive to maintain environmental quality of an urban region or modified land uses of fringes.

That the urban landscape constituted a region was explained by Dickinson RE in his book City Region and regionalism in 1947. Around the city lies its hinterland with which it has intense interaction and for which it forms the focal point (Ghosh S.). This generated functional kindred interests and common organisations brought together into being through the medium of routes that bind it to the urban centre. The city and the area around it constitutes the City Region. The regional character remains strongest around the focus, becomes least visible as one moves outward where it finally dissipates. The delimitation of a city region is a complex process based on various criteria which differ for all practical purposes is a constituent part of the urban centre and is conveniently designated as outer zone. This outer zone of the city is perceived and used differently by the different urban economic groups. To those who can afford to travel fast and with ease, the outskirts offer better living conditions.

Although to a much specific terminology, the outer city landscape thus does not develop uniformly; before the urban landscape ends and typical rural space use begins, the land use pattern can be classed into two broad types: i) the residential suburb and the ii)urban fringe zone. Residential suburbs happen to be middle and upperclass residential enclaves. Those who can afford commuting to and from work and wish to escape the congestion of the inner city may choose to reside here. Situated at the periphery of the city these areas develop small service centres to cater the population in neighbourhood. There may be a school or a bank, but any further complexity of functions may turn into a Satellite Township. Suburbs which once were defined as mysterious phenomena, during the city planning and depolarisation activities stand to be the obvious choice for relocating excess population. This process of amalgamation slowly goes in steady adjust to the municipal boundaries. The rural-urban fringe in distinctly identified around Indian cities. Beyond the urban core area, the urban amenities thin out, but the residential density changes only slightly until one moves out considerably. Cultural geographers see suburbs are often considered as creative places of popular culture, models of post-modern individuality with suburban architecture. Bengaluru through its radial expansion sees suburbs as the best alternatives to relocate its population and most of its functions.

\section{Expansion of Urban and Dissolution of Suburban}

The percentage of rural population of the state of Karnataka has been recording a decreasing trend (from $75.69 \%$ in 1971 to $61.43 \%$ in 2011 ) where as that of the percentage of urban population is increasing considerably from $32.19 \%$ in 1971 to $61.43 \%$ in 2011 . The per- 
centage of rural population in Bengaluru Metropolitan Region had decreased drastically from $44.56 \%$ in 1971 to $15.02 \%$ in 2011 , where as the percentage of urban population had increased from $55.44 \%$ in 1971 to $84.98 \%$ in 2011 . Hence it may be concluded that both Karnataka and Bengaluru Metropolitan Area had undergone a great deal of urbanisation, a typical feature of a developing nation. As far as the report prepared by the Census of India, 2011 is concerned it shows that Bengaluru Urban Area constituted of over $92 \%$ of core area in 1971 and some $7.4 \%$ area of it could be termed periphery. The percentage share of fringe area of Bengaluru that has been very much included to Bengaluru City in the conurbation area has been on steady rise to $15.2 \%$ in $1981,35.6 \%$ in $1991,24.6 \%$ in 2001 and to $20.7 \%$ in 2011 (though at a somewhat lower rate of growth). The statistics reveal this picture clearly once again with diminishing area under core Bengaluru and rising areas under periphery (Table 1 ).

\section{Area of Study}

Bengaluru (Rural) District in its present form came into being in 2007, after Ramanagara district was carved out of this district. In 1986, Bengaluru district was divided into Bangalore (Urban) and Bengaluru (Rural) districts. Originally, Bengaluru (Rural) district comprised eight Taluks namely Channapattana, Kanakapura, Magadi, Ramanagara, Devanahalli, Doddaballapura, Hosakote and Nelamangala. When Ramanagara district was formed in 2007, only four Taluks namely Devanahalli, Doddaballapura, Hosakote and Nelamangala remained with Bengaluru (Rural) district. Bengaluru city itself is the headquarters of the district. It is a compact district with proximity to Bengaluru city. Hosakote taluk has five Hoblis including kasaba, the other four being Sulibele, Anugondanahalli, Jadigenahalli and Nandagudi within Hosakote. There had been 22 Gram Panchayats and one municipality in the taluk. Hosakote, the headquarters of the taluk, is situated at a distance of 12 kilometres from Bengaluru city towards its north eastern fringes. The occupation in the taluk is mainly agriculture, the other important activities being beekeeping and horticulture. Nandagudi hobli had been chosen for the development of a Township area in co-ordination to Bengaluru's growing population, to be just another alternative for city-like living. The rapid growth of Bengaluru over the past decades has resulted in growth beyond the core area into Bengaluru Urban and Rural districts. With increasing population, stress on the urban services and an objective to spread the growth around the city, the Planning Authority had planned to set up five satellite
Table 1. Percentage Area covered under Core and Periphery areas under Bengaluru Urban Area (1971-2011)

\begin{tabular}{ccc} 
Year & Periphery & Core \\
\hline 1971 & 7.4 & 92.6 \\
1981 & 15.2 & 84.8 \\
1991 & 35.6 & 64.4 \\
2001 & 24.6 & 75.4
\end{tabular}

Data Source: Census of India (2011).

townships and self sustainable cities. The objective of developing these townships is to have a more rational and better use of land and water resource, and more equitable and efficient distribution of communication and technical facilities. The townships would have modern transport linkages to main city to facilitate efficient transport. With the development of these townships, the pattern of growth would become "huband spoke" based with decentralised development. This paper highlights many such features of Namdagudi Township at the fringes of Bengaluru, likely to come up as a planned alternative to ease the pressure on the primate city of Karnataka (Map 1).

\section{Historical Evolution}

Eminent historian Suryanath Kamath cites records which dates back to $1530 \mathrm{AD}$, that reveals that once Nandagudi happened to be the headquarter of an administrative unit (Sthala) called Nandaguli in the southern Chola dynasties. Also, Nandagudi had been sometimes referred to as 'Nanjiguli' under Sugatur Seeme. Tamil records mention the place as Nondukolli. Earlier, under the Cholas, it was called Kaivaranadu. Under the Hoysalas, Nandagudi became the headquarters of Naadu clan, mentioned Kamath. The Nandagudi village was situated at the foot of a laterite hillock and a small cave which housed a renovated Mutyalamma temple - the village goddess. The temple pillars reveal many relief sculptures carved in the Vijayanagara style. Nandagudi, had been said to have been the capital of Uttunga Bhuja, whose nephews, the Nanda princes, imprisoned by him secured their release and seized the kingdom. These accounts support a rich heritage backdrop of the region, situated in the north eastern periphery of the city of Bengaluru (Figure 1a).

\section{Present Land Use and its People of Nandagudi}

As far as the land use of the study area is concerned, about $30 \%$ of the people of the Hoskote taluk are mostly dependent on primary sector; and similarly the village Nandagudi (within the Hoskote taluk) too 


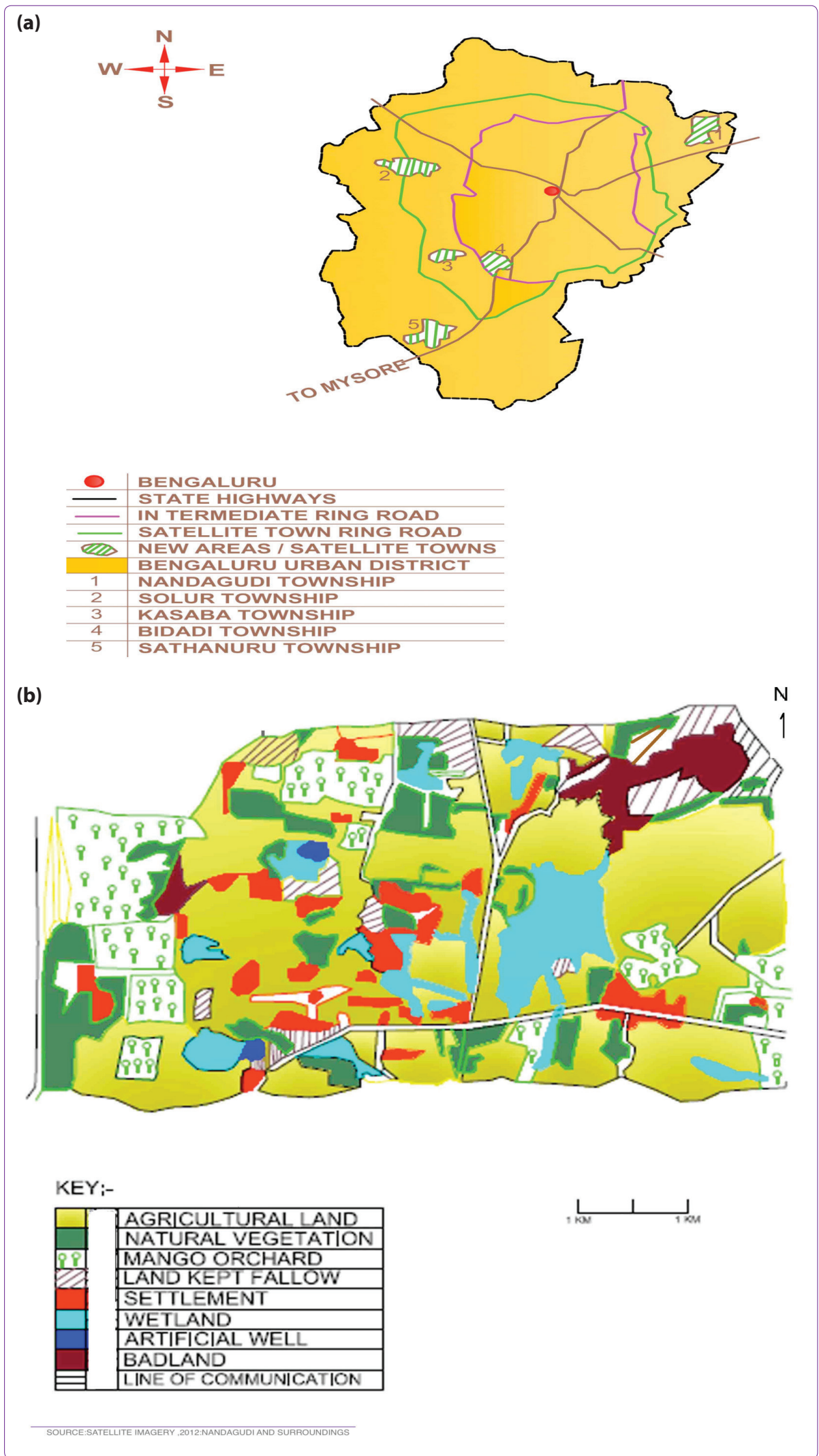

Figure 1. (a) Locatıon of the Satellite Towns Around The City of Bengaluru. Source: Bengaluru City Development Plan: Vision Documents (2025). (b) Present Land Use Map of Nandagudı Hoblı Covered Under The Satellite Township Project. Data Source: Satellite Imagery, Nandagudi Hobli, 2012 \& as computed by author. 
shows major occupation of the people to be agricultural. Horticulture and Bee keeping activities are also carried out by the village dwellers. Several types of crops are grown depending upon the availability of water. The major crops grown here in this area are Ragi, Paddy, Jowar, Pulses, Oil seeds during southwest monsoon period and vegetables are cultivated during pre-monsoon period. The low lying valleys and depressions are intensely cultivated mainly (irrigated) dry crops, vegetables and paddy cultivation. Also in recent times grape and mango orchards management and cultivation have been taken up which appear to be financially more remunerative (Figure 1b).

This area is generally a low rainfall area and the cultivators had drilled out bore wells to meet the demand of water for irrigating the farm lands. Another reason for digging these bore wells has been the steady drying up of the dug wells, which were in use earlier. There had been a continuous and of course rising demand for vegetables and fruits in Bengaluru city. As a result, production of vegetables and fruits in the land irrigated by tanks and wells has now become a characteristic feature of the entire Nandagudi Hobli. The contribution of horticulture to the regional economy of Nandagudi is quite substantial. The soil conditions are suited for growing horticulture crops. The major vegetable crops are tomato, cabbage, beetroot, beans, green chillies, carrot etc. The major commercial flowers grown here are chrysanthemum, rose, aster and marigold. Bee keeping is also a well practiced occupation here based on agriculture, horticulture and forest areas. The Bee keeping is also considered as a part of rural industry. The Bee keeping industry had covered 49 villages of Hoskote taluk including Nandagudi and only a meagre percentage of population here depends (only $2 \%$ ) on secondary sector. The people who are engaged in non farming activities are mainly found to be engaged in manufacturing and processing units. Also, about $16 \%$ of the people of this region depend on tertiary sector. They are engaged in service, transportation, financial oriented and other allied activities. For more than past 15 years, the Banyan and Peepal trees of Ramagovindapura near Nandagudi had hosted hundreds of colonies of the Giant Asian Honey Bee (Apis dorsata). The pollinating efforts of these bees have (according to the villagers) increased the crop yields of the surrounding area, their defecation flights have enhanced soil fertility and they have put the village on the map as a tourist attraction less than 40 kilometres from the city of Bengaluru.

Situated $45 \mathrm{~km}$ from Bengaluru in Hoskote taluk, Nandagudi hobli had been involved in silkwormrearing (sericulture) from the 1780 s and the village got involved in milk production only later. It had been

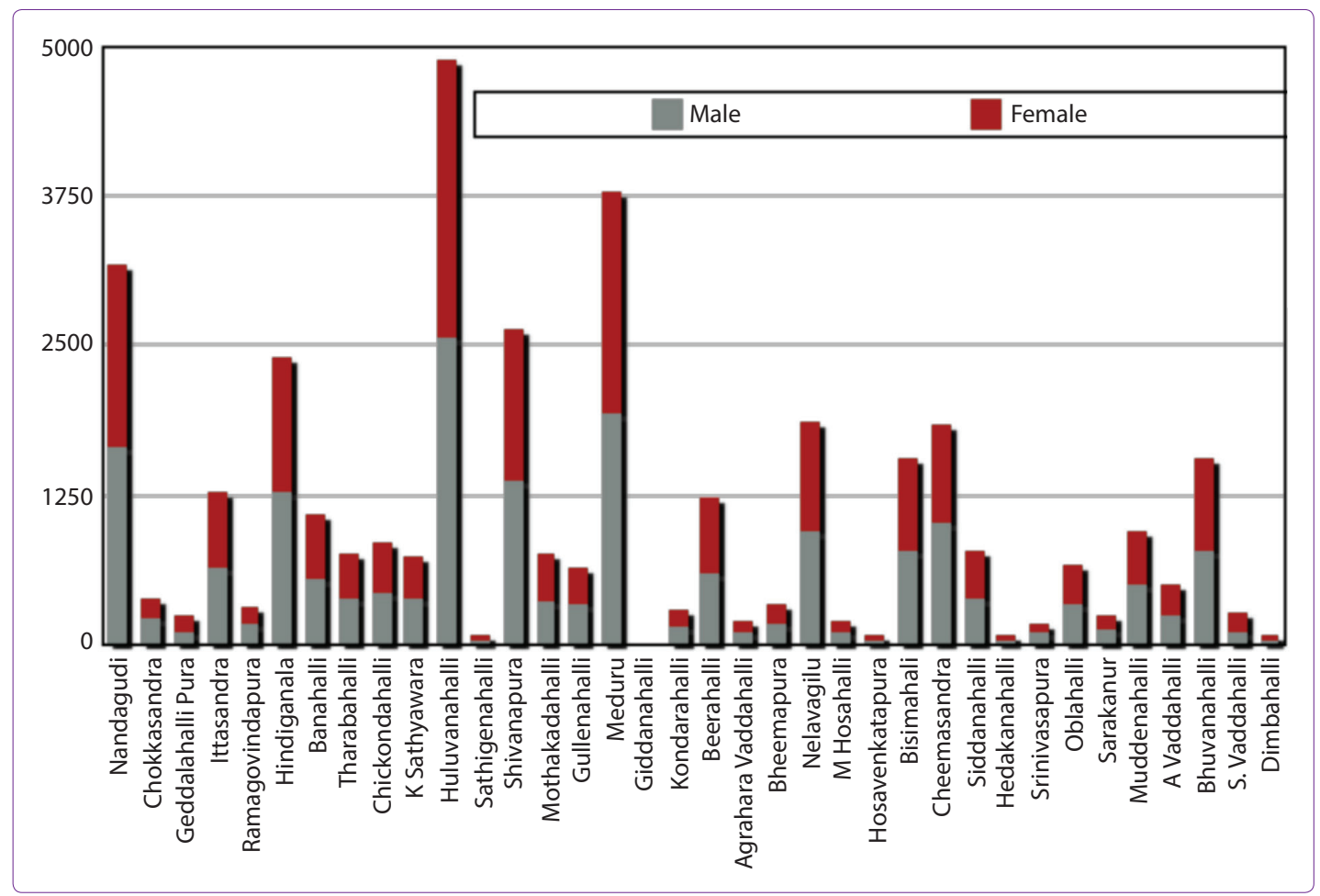

Figure 2. Distribution of population in the selected villages under Nandagudi Project (2011). Data Source: Hoskote Municipal Corporation, 2011. 
stated by various historical records that Tipu Sultan introduced sericulture in Hoskote during the early 1780s, along with Chennapatna and Ramanagaram. Since then, the silk traders from this village competed with Chennapatna's traders and met a major part of the demand from Mysore state," explains Arun Prasad, research head, Discover Bengaluru. Even today, most of the villagers are engaged in sericulture. This in turn, provides employment to many others. Dairy products prepared in Nandagudi and its vicinity meet the demand of parts of Bengaluru, Chintamani and Kolar districts of Karnataka. A small village near Nandagudi - Idigenehalli - contributes about 2,750 litres of milk every day. Of late, even vegetables are being grown in the area.

\section{Demographic Profile}

As far as population profile is concerned the villages covered under the Nandagudi Township show a picture with variety. There have been 36 villages of Nandagudi Hobli of Hoskote taluk delineated for the upcoming project of building a new urban area The villages like Huluvanahlli, Meduru, Nandagudi, Shivanapura and Hindiganala represent relatively higher concentration of population. Though the remaining villages of the Satellite Township project area moderate to low population. However, overall the of region show maximum population touching nearly 5000 concentrating in Huluvanahalli. Interestingly, the project area includes villages like Geddalahalli Pura, Banahalli, Chikkondahalli, Mothakadahalli, Beerahalli, Hosavenkantapura, Hedakanahalli, Sarakanur and S. Vaddahalli which show dominance of female population over the males (Figure 2).
On the other hand given the average distribution of population in the villages covered under the project area, only few (9 out of 36 villages) exhibit population concentration more than the mean distribution ( $Z$ score) and the remaining 27 villages exhibit little or scanty population distribution as measured from mean (Figure 3). This is an important indicator for planning regionally; the scantily populated villages can be designated as well preferred sites for urban development and decentralisation initiatives for Bengaluru city. But there also remains some dilemma for the early residents of the region demarcated, in relation to evacuation and rehabilitation programme. Decadally speaking the villages covered under the project show an overall expanding population that may be attributed to natural increase and rural to rural migration (from the remotest village to a village at the neighbourhood of urban primacy of Bengaluru). However villages like Sathigenahalli, Gullenahalli, Agrahara Vaddahalli, Siddanahalli and Giddanahalli show negative growth of population; that may be attributed to the push factors acting behind out migration. People here have moved out for last few decades in search of employment opportunities and lack of the same in these underdeveloped pockets, keeping these places of origin under-populated (Figure 4a). However, the remaining 31 villages demarcated for the project exhibit positive growth of population (Figure $4 b$ ). Here remains the challenge of providing these villages a good compensation as land held by them would be acquired, either in the form of financial benefits or providing them the guarantee of employment. A village called Cheemasandra earmarked for the township project,

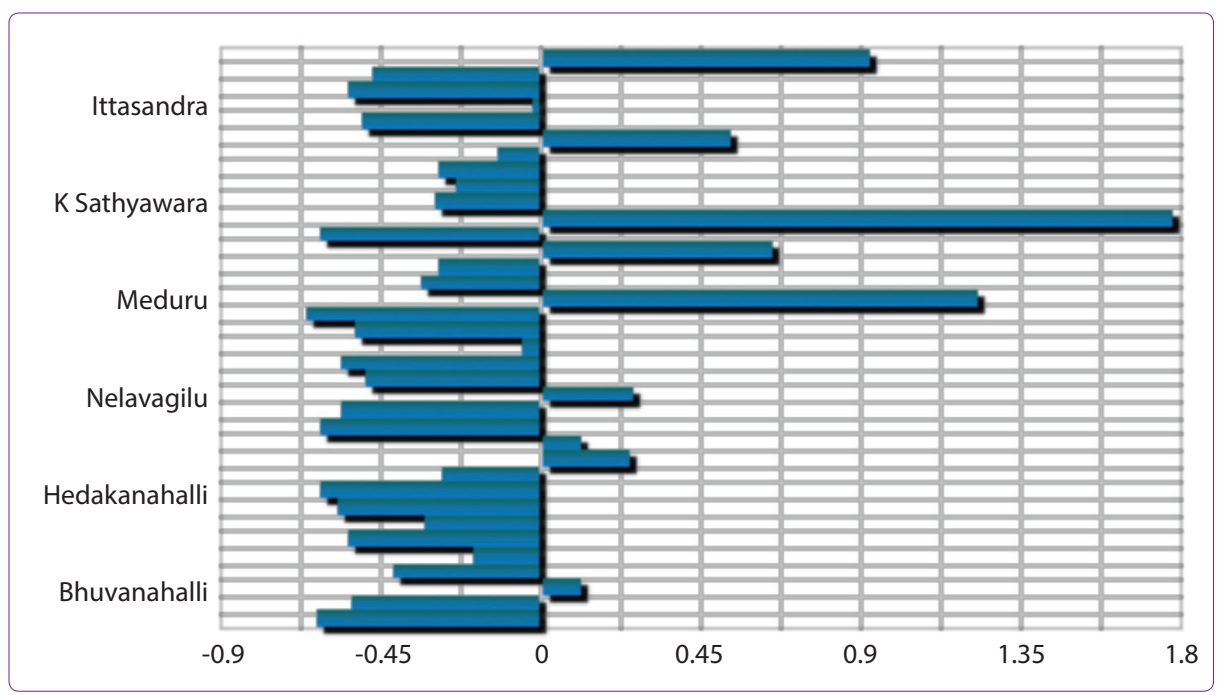

Figure 3. Distribution of population in the villages of the Study Area by Z-Score (2011). Data Source: Hoskote Municipal Corporation, 2011. 


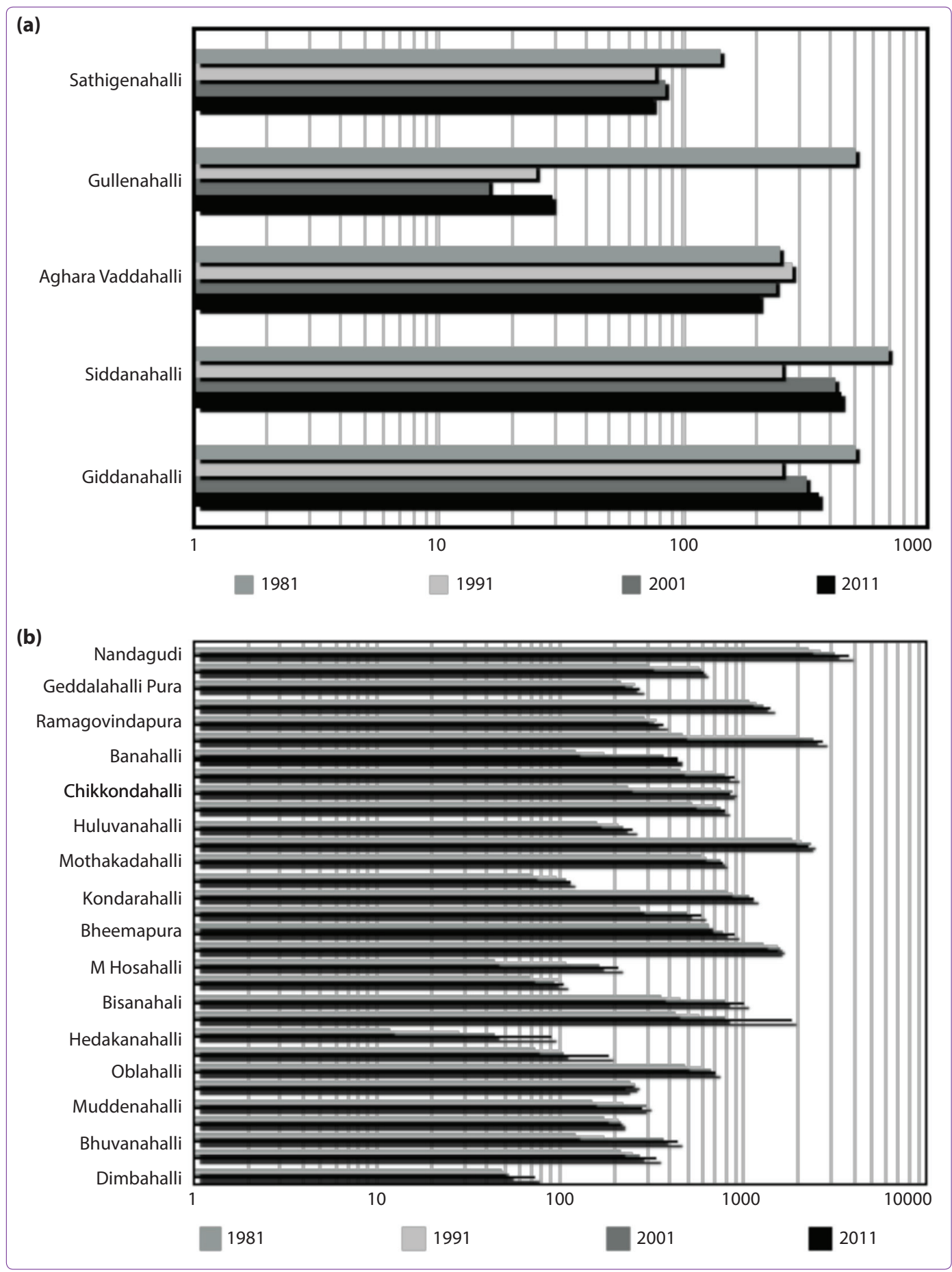

Figure 4. (a) Distribution of population of villages under Nandagudi Project which record negative decadal growth. Data Source: Provisional Population Totals; Paper 1of 2011: Village Details: Karnataka (2011). (b) Decadal distribution of population in the remaining villages under the Nandagudi Project that reveal an ever-increasing population (1981-2011). Data Source: Provisional Population Totals; Paper 1of 2011: Village Details: Karnataka (2011).

includes at least 50 families each in mulberry and ragi crop production; other 30 families remain engaged in vegetables, paddy, corn, flower and fruit production. Villagers own quite a good number of sheep and goat and Nandagudi area as a whole supply a good percent- age share of the city's daily milk requirement.

\section{Emerging Satellite Township of Nandagudi}

Within the overall governance paradigm, urban governance is defined by the United Nations Human 
Settlements Program (UN-HABITAT) as the sum of the many ways individuals and institutions, public and private, plan and manage the common affairs of the city. It is a continuing process through which conflicting or diverse interests may be accommodated and co-operative action can be taken. It includes formal institutions as well as informal arrangements and the social capital of citizens' (UN-HABITAT, 2002: 14). Following this the state cabinet's decision was to develop eight clusters around Bengaluru, not only to decongest it but also to pull up the growth of its peripheries. The strategy of Metropolitan development generally suggest a radial corridor grown concept of Metropolis. In this concept, the Metropolitan centre like Bengaluru as continues to dominate the metropolitan region and its hinterland, numerous growth centres of nodes originate in the process. These nodes emerge to be potential areas for development as independent urban centres and they eventually play important roles to 'share' the loads of the Primate City. The state government, in 2006, had announced that it would develop townships near Nandagudi in Hoskote, Kasaba and Bidadi in Ramanagaram, Solur in Magadi, and Sathanur in Kanakapura. The townships were supposed to be interconnected with two ring roads-Bangalore Metropolitan Region Satellite Townships Ring Road and Bangalore Metropolitan Region Intermediate Ring Road-with the assistance of National High Ways Authority of India (NHAI). The state government had proposed to develop wide roads in these townships, besides developing independent airstrips and helipads.

The Structural Plan of the city is based on the governing principle of "Structured Continuity." This principle directs that development in existing urbanised areas and new extensions must be "structured" spatially and functionally to avoid unmanaged urban sprawl. Existing urban patterns must be strengthened through urban renewal and proposed development must be "continued" by selective extension of already developed areas. This will avoid new developments in distant outskirts that are not serviced by infrastructure and transportation. This plan envisions that development will be spatially organised in five concentric belts. The first belt includes the core area consisting of the Administrative Centre and the Central Business District; the second belt encompasses Peri-central area with older planned residential areas surrounding the core area; the third belt is the recent extensions (2003) of the City flanking in both sides of the Outer Ring Road, a portion of which lacks services and infrastructure facilities and is termed as a shadow area; the fourth belt includes new layouts with some vacant lots and agricultural lands; and the fringing belt is the Green belt and agricultural area in the City's outskirts including small villages.

According to R.E. Pahl (1965), one of the most interesting feature of urbanisation process in the city fringe, is definitely the collapse of its geographical characteristics. Nandagudi under the process of town formation would undergo urban penetration from the Bengaluru city itself with certain degree loss of the agricultural fields. Culture is increasingly being recognised as the key to sustainable economic and social development. Sir Peter Hall, in his book 'Cities in Civilization', has mentioned that culture, technology, and order would bring the 'coming golden urban age'. But rapid urbanisation also brings with it social exclusion of the poor, intensifying the problem of poverty and diminishing equity. The other consequence of the fast pace of urbanisation is unsustainable resource uses and environmental degradation with growing impacts on human and economic health. Then it becomes essential to look into the matter in a more sympathetic way where development would ensure economic growth but also address to the environmental issues in the context of land use.

\section{And the Dilemma...}

An opportunity exists to set aside and protect these valuable natural treasures as a World Heritage Site (WHS); a long and burdensome project. At one point in 2008 there were plans on the books to turn the areas into Special Economic Zones slated for development; local beekeepers and ecologists managed to organize and thwart the plan. However as long as the area exists unprotected there will be threats such as the "New Integrated Townships in the Bengaluru Metropolitan Region" proposal which may threaten the area. These plans, which are opposed by the agricultural residents of the Nandagudi township and the village of Ramagovindapura, are most likely not in the best interests of the bees nor the local farmers. The rural agricultural setting where the bees are nesting has, in the past, fended off urban-sprawl governmental development plans including a Special Economic Zone (SEZ) initiative and an attempt by the Bengaluru Metropolitan Region (BMR) to develop a "Satellite City" in the region. Although the need for rational expansion of the rapidly growing city of Bangalore cannot be dismissed, little consideration has been given, nor input taken from the villagers. The effects of urbanization on the dorsata bee populations would be understandably negative, primarily because of loss of forage potential. Picturesque Hosakote is regarded as the archetypal land of milk and honey with a lot of happy go lucky folk, the idyllic 
picture of a rural life. More than 50,000 litres of milk is produced per day in Nandagudi Hobli itself. Annually, about Rupees 200 crore worth of silk is produced in this area. We dont know why the government wants to endanger our economic existence," wails Krishnappa of Ittasandra, one of most effected villages. Milk, fruits and vegetables from Nandagudi have long sustained Bengaluru; the hobli also provides the city flowers and raw silk. Each day, 120 tonnes of vegetables are transported from Nandagudi to the primate city - this, according to the local farmers, is one-third of Bengaluru's daily vegetable requirement. Added to this Nandagudi produces approximately six lakh litres of milk and 150 tonnes of silk cocoons a month. Krishnappa, a medium holdings farmer, earns Rs 45,000 a month from selling roses alone. He is understandably vehement in his condemnation of the Special Economic Zone project.

"When Bangalore wanted vegetables, we grew them. Then they wanted flowers, we grew that. Now they are saying they want something else, so we should give up our land. Every time someone changes their mind in Bangalore, our lives change." (Krishnappa, a local resident).

\section{Recommendations}

Regions require various land uses; protection of farmland, cities, industrial space, transportation hubs and infrastructure, military bases, and wilderness. Regional planning is the science of efficient placement of infrastructure and zoning for the sustainable growth of a region. Advocates for regional planning such as new urbanist Peter Calthorpe, promote the approach because it can address region-wide environmental, social, and economic issues which may necessarily require a regional focus.Keeping this in mind,it can be stated that two phrases 'sustainability' and 'growth' should not be treated as mutually exclusive. Urban expansion of Bengaluru radially can be attributed to peripheral developments into new satellite towns; but their rural and if not rural, rurban fringes should be nurtured in a more thoughtful way. The meaningful way should be such that if planners propose a town building approach in Nandagudi then it should retain its rural characteristics given an Urban Village status. It has been aspired to be an independent and self-contained human settlement, a unique integrated land-use concept aimed at (achieving a) work-home relationship. In plain speak, this is a projection of the "work-live-play" concept currently much touted among global real estate and infrastructure companies. The region would be divided into five zones - industrial, commercial, residential, knowledge and recreation and leisure as well. The sectors that would set up manufacturing units under the industrial zone that would comprise: information technology and IT-enabled services, automobiles, microelectronics, diamond-processing, bio-technology, knowledge process outsourcing and healthcare. So far, as it has been discussed various aspects of the dispersal of Bengaluru's population from the existing overly concentrated settlements, one can never ignore the good qualities of village lives.Although this means village life shouldn't be altered and its pattern should be retained with local dwellings and its pre-existing morphology, but a plan for relocation always creates inconvenience for such rural entities (Kennedy,1958,164-5).Challenges are indeed generated when the urban planners plan for developing villages into a complete location of decentralised urban centres, that specifically depend on complex interplay of the nature of the sites chosen, the size of the villages, the duration of the emergency and the extent to which basic facilities like hospitals and schools are provided. It would be justified if a balanced land use development in terms of retaining agricultural field, waterbodies along with the provision of basic infrastructures, that were missing so far may actually speed up the 'growth' of the rural sites along with the aims of urban decongestion can be achieved.

\section{Conclusion}

The evening out of regional disparities in development within the Indian Union was one of the main socio-economic objectives in the Second Five Year Plan. In practice, however the trend has perhaps been for the developed areas to become more developed and for the backward areas to fall farther behind. This trend would probably have been similar or stronger under a free enterprise economy. Maintaining Nandagudi like an Urban Village catering to the needs of growing urban population of the primate city through residential opportunities, encompassing the work-liveplay mantra that may be prove to be ideal.

\section{References}

Bhattacharya B. (2010) Urbanisation, Urban Sustainability and the Future of Cities Concept Publishing Company Pvt. Ltd. New Delhi, India pp.310-389.

Carter, H. (1995) The Study of Urban Geography, Arnold, a division of the Hodder Headline PLC, London.

Chasolm, M. (1979) Rural Settlement and Land Use,An Essay in Location. Hutchinson \& Co. Ltd., London.

Cumbers A., Mackinnon D. (2006) Ed., Clusters in Urban and Regional Development, Routledge NY pp.8-14.

Das A. K. (2007) Urban Planning in India, Rawat Publications, Jaipur pp. 122-128.

Glasson, J. (1974) An Introduction to Regional Planning: 
Concepts, Theory and Practice. Hutchinson \& Co. Ltd., London.

Government of India. (2001) Provisional Population Totals

Paper1 of 2011: Karnataka, Census of India, New Delhi.

Government of India. (2001) Provisional Population Totals

Paper2 of 2011: Karnataka, Census of India, New Delhi.

Loughlin, J. (1951) Urban and Regional Planning: A Systems Approach, Faber \& Faber Ltd., London.

Mandal, R. B. (2000) Urban Geography's Textbook, Concept Publishing Company, New Delhi.

Nadarjah, M., Jama-moto, A.T., (2006) Ed., Urban Crisis: Culture and Sustainability of Cities, Rawat Publications, New Delhi.

Sharp, T. (1968) Town \& Townscape, Jerrold \& Sons Ltd., UK. Verma L.N., (2008) Urban Geography, Rawat Publications, New Delhi.

\section{Websites References}

1. http://timesofindia.indiatimes.com/city/bangalore/ States-largest-SEZ-may-shut-shop/articleshow/4717565. $\mathrm{cms}$

2. http://www.ces.iisc.ernet.in/biodiversity/sdev/news/ towmships\%20around\%20bangalore.pdf

3. www.apinews.com/en/technical-articles/others/item/ download/1237

4. http://archive.tehelka.com/story_main34.asp?filename $=c r 131007 N E W N A N D I G R A M . a s p$

Key words: City region; satellite township; special economic zone; suburb; urban village.

Anahtar sözcükler: Kent bölgesi; uydu ilçe; özel ekonomik bölge; uydu kent; köykent. 